\title{
Epidermio augimo veiksnio receptoriaus geno pažaidos sergant nesmulkiųjų ląstelių plaučių vẻžiu
}

\author{
Neringa Vagulienė, Marius Žemaitis \\ LSMU MA Pulmonologijos ir imunologijos klinika
}

Reikšminiai žodžiai: nesmulkiujų ląstelių plaučių vežys, EGFR geno mutacijos, tirozino kinazės inhibitoriai.

Santrauka. Plaučių vezžys - viena labiausiai paplitusių ir didžiausią mirtingumą sąlygojančių onkologinių ligų visame pasaulyje. Nepaisant visuomenės švietimo ir šiuolaikinių diagnostikos metodų, nesmulkiujų ląstelių plaučių vėžys nustatomas toli pažengusių stadijų, kai reikalingas sisteminis plaučių vėžio gydymas. Molekulinės biologijos atradimai sudaro prielaidas onkologinių ligụ ankstyvai diagnostikai, prognozinių ir predikcinių veiksnių atradimui, gydymo optimizavimui.

Kasmet nuo plaučiu véžio miršta per milijoną žmonių [1]. Tai aktuali medicinos ir socialiné problema. Lietuvos vėžio registro duomenimis, $2009 \mathrm{~m}$. vèlyvos stadijos (III, IV) plaučiu vėžys nustatytas net 63 proc. ligoniụ [2]. Dar nesenai chemoterapija platinos pagrindu buvo pagrindinis išplitusio nesmulkiụjų ląstelių plaučiu vėžio (NSLPV) gydymo metodas, deja, atsakas i chemoterapiją pasireiškia tik $30-40$ proc. pacientu. Be to, greitai igyjamas atsparumas jai, ir chemoterapijos preparatais gydomu pacientu vidutinè gyvenimo trukmès mediana tèra tik 8-10 ménesių. Vèlyvų stadijų NSLPV gydymas ivairiais platinos dupletu deriniais nepailgino gyvenimo trukmès, triju vaistu deriniai taip pat nedave laukiamo efekto. Tinkamumas skirti chemoterapiją nustatomas ìvertinus funkcinę ligonio būklę, amžių, gretutines ligas. Chemoterapija platinos pagrindu gali būti taikoma tik geros funkcinès būklès pacientams, tuo tarpu vyresnio amžiaus ir blogos funkcinès būklès pacientų gydymo galimybès iki šiol buvo ribotos.

Molekulinès biologijos atradimai sudaro prielaidas onkologinių ligu ankstyvai diagnostikai, prognozinių ir predikcinių veiksnių atradimui, gydymo optimizavimui. Mokslininkai ieško naujų molekulinių žymenų ir tiria jau žinomų prognozinę bei predikcinę vertę, nes gydymo individualizavimas yra viena iš prioritetinių onkologijos krypčių. Kaip plaučiu véžio diagnostiniai, predikciniai ir prognoziniai rodikliai plačiai tyrinëjami šie molekuliniai žymenys: epidermio augimo veiksnio receptorius (angl. epidermal growth factor receptor, EGFR), MET receptorius, VEGF, VEGF receptorius, KRAS, HER2 re- ceptorius, EMLK4-ALK, PIC3CA, seBRAF, IGF-1R [3]. Dabar plaučiu vėžiui gydyti taikoma biologinè (taikinių) terapija slopinant EGFR aktyvumą navikinèse ląstelèse bei VEGF. Tačiau kol kas nustatyta, kad tik epidermio augimo veiksnio receptoriaus geno mutacijos susijusios su klinikiniu EGFR tirozino kinazių inhibitorių (TKI) veiksmingumu.

EGFR yra žmogaus epidermio augimo veiksnio receptoriu (angl. human epidermal growth factor receptor, $H E R / E r b B)$ šeimos receptorinè tirozino kinaze, kurios domeno mutacijos 18-21 egzonuose sergant NSLPV pirmą kartą nustatytos 2004 metu pabaigoje $[4,5]$. Šio transmembraninio receptoriaus padidèjęs aktyvumas dèl EGFR geno stipresnès raiškos, amplifikacijos, aktyvuojančių mutacijų ar ligandų (EGF, TGF $\alpha$, amfiregulinas) stipresnès raiškos yra susijęs su plaučiu veežio genezès ir plètotès procesais, nes skatina vėžinių ląsteliụ dauginimąsi, metastazavimą, atsparumą antinavikiniams vaistams, nauju kraujagysliu formavimąsi navike bei slopina šių ląstelių žūtị [6]. Baltụjų rasès NSLPV ligoniu grupèje EGFR geno mutacijų pasireiškimo dažnumas siekia apie 10 proc., tuo tarpu azijiečiuc - net iki 40 proc. $[7,8,9,10]$. Literatūros duomenimis, EGFR geno mutacijos navikiniame plaučiu audinyje dažniau nustatomos esant adenokarcinomos histologiniam plaučiu vèžio tipui, moterims bei nerūkantiems NSLPV ligoniams $[7,8,9,11]$.

EGFR geno mutacijų nustatymas leidžia prognozuoti ligos agresyvumą, jautrumą gydymui, kurio laipsnis gali būti susijęs su EGFR geno didesniu aktyvumu bei 
turèti ịtakos ligos predikcijai ir prognozei. Taigi šio receptoriaus ir jo signalo perdavimo keliai yra reikšmingi vėžio terapijos taikiniai [12]. EGFR TKI blokuoja EGFR perduodamų augimo signalų sklidimą ir taip sulètina vèžinių ląstelių dauginimąsi [13]. Literatūros duomenimis, EGFR mutacijos, kurios siejamos su atsaku ì gydymą EGFR TKI, 44 proc. atvejų yra nukleotidu delecija 19 egzone ir 41 proc. 21 egzono mutacija L858R [14]. Šiu mutacijų radimas koreliuoja su klinikiniais ir morfologiniais veiksniais, kurie siejami su jautrumu gydymui EGFR TKI [15]. Keletas klinikinių tyrimų nustatè, kad būtent nukleotidu delecija 19 egzone susijusi su ilgesne gyvenimo trukme skiriant gydymą EGFR TKI nei 21 egzono mutacija L858R $[14,16]$.

EGFR TKI - tai mažos molekulinès masès inhibitoriai, kurie jungiasi prie EGFR domeno ir slopina proliferacinių signalų perdavimą. Gydymas EGFR TKI taikomas išplitusio ar metastazavusio plaučių vẻžio atvejais, kai negalimas radikalus gydymas. Europos Sąjungoje ir Lietuvoje NSLPV gydyti patvirtinti du EGFR TKI: erlotinibas ir gefitinibas.

Pirmas III fazès klinikinis tyrimas I eilès gydymui EGFR TKI ịvertinti, tiriant išplitusiu ar metastazavusiu plaučių vẻžiu sergančius pacientus ir jo veiksmingumą lyginant su standartine chemoterapija, buvo atliktas Azijoje [17]. Šio tyrimo duomenimis, esant EGFR geno mutacijų, atsakas i gydymo TKI (gefitinibu) siekia 71,2 proc., o gyvenimo iki ligos progresavimo mediana yra 9,6 mènesių. Kitas III fazès klinikinis tyrimas EURTAC buvo atliktas Europoje, o tiriamųjų kontingentą sudarè kaukaziečių rasės pacientai [18]. Šiuo tyrimu nustatyta, kad esant EGFR geno mutacijų, atsakas i̇ gydymą erlotinibu siekia 54,3 proc., o gyvenimo iki ligos progresavimo mediana yra 9,7 ménesių. OPTIMAL III fazès klinikinio tyrimo rezultatai buvo panašūs i anksčiau aptartųjų [19].

Biologinė terapija EGFR TKI, priešingai nei iprastinè chemoterapija, gerai toleruojama. Pagrindiniai šalutiniai reiškiniai - odos išbèrimas ir viduriavimas, bet dažniausiai jie būna lengvi ar vidutinio sunkumo, lengvai pašalinami ṫprastomis priemonėmis ar pakeitus vaisto dozę. Kiti šalutiniai reiškiniai, kaip antai gleivinių, akių pažeidimas, bilirubinų kiekio padidejjimas ar intersticinis pneumonitas, pasitaiko labai retai. Be to, iprastine chemoterapija galima tik geros funkcinès būklès plaučiu vèžio ligoniams, tuo tarpu gerai toleruojamas ir efektyvus gydymas EGFR TKI gali būti skiriamas ir blogesnès būklès pacientams.

EGFR geno mutacijos Europoje ir pasaulyje tiriamos prieš priimant sprendimą dèl NSLPV sisteminio gydymo. Taigi išplitusio ar metastazavusio NSLPV gydymo pasirinkimą lemia tiek klinikinès (funkcinė būklè, gretutinès ligos), tiek biologinès charakteristikos (histologija, EGFR geno mutacijos). Biologinè (taikinių) terapija atrinktiems pacientams pailgina gyvenimo trukmę, atitolina ligos progresavimą, geriau toleruojama, palyginti su standartine chemoterapija.

\section{EPIDERMAL GROWTH FACTOR RECEPTOR GENE MUTATIONS IN ADVANCED NON SMALL CELL LUNG CANCER}

\author{
NERINGA VAGULIENE், MARIUS ŽEMAITIS \\ DEPARTMENT OF PULMONOLOGY AND IMMUNOLOGY \\ LITHUANIAN UNIVERSITY OF HEALTH SCIENCES
}

Keywords: non-small cell lung cancer; EGFR gene mutations; tyrosine kinase inhibitor. Summary. Lung cancer is the major cause of cancer-related mortality in men and women worldwide. NSCLC comprise the majority of cases, and the prognosis of patients diagnosed with advanced NSCLC continues to be dismal. The development of personalized medicine with a focus on novel targeted therapies has supplanted the one-size-fitsall approach to the treatment of many cancers, including non-small cell lung cancer.

\section{LITERATŪRA}

1. Jemal A, Siegel R, Xu J, Ward E. Cancer statistics, 2010. CA Cancer J Clin 2010; 60: 277-300.

2. Lietuvos vėžio registras http://www.vuoi.lt/?457134211.

3. Janku F, Stewart DJ, Kurzrock R. Targeted therapy in non-small-cell lung cancer - is it becoming a reality? Nat Rev Clin Oncol 2010; 28: 5311-20.

4. Lynch TJ, Bell DW, Sordella R et all. Activatig mutations in the epidermal growth factor receptor underlying responsiveness of non-small cell lung cancer to gefitinib. N. Engl J Med 2004; 350: 2129-2139.

5. Paez JG, Janne PA Lee JC, et al. EGFR mutations in lung cancer: correlation with clinical response to gefitinib therapy. Science 2004; 304: 1497-1500.

6. Normanno N, De Luca A, Bianco C, Strizzi L, Mancino M, Maiello MR, Carotenuto A, De Feo G, Caponigro F, Salomon DS. Epidermal growth factor receptor (EGFR) signaling in cancer. Gene. 2006 Jan 17; 366: 2-16.

7. Shigematsu H, Lin L, Takahashi T et al. Clinical and biological features associated with epidermal growth factor receptor gene mutations in lung cancer. J Natl Cancer Inst. 2005; 97: 339-346.

8. Rosell R, Moran T, Queralt C, etal. Spanish Lung Cancer Group. Screening for epidermal growth factor receptor mutations in lung cancer. $\mathrm{N}$ Engl J Med. 2009 Sep 3; 361(10): 958-67.

9. Marchetti A, Marrtella C, Felicioni L, et al. EGFR mutations in non-small-cel lung cancer: analysis of a large series of cases and development of a rapid and sensitive method for diagnostic screening with potential implications 0 pharmacologic treatment. J Clin Oncol 2005; 23: 857-65.

10. Kosaka T, Yatabe $Y$, Endoh H, Kuwano H, takahashi T, Mitsudomi T. Mutations of the epidermal growth factor receptor gene in lung cancer: biological and clinical implications. Cancer Res 2004; 64: 8919-23.

11. Marks JL, Broderick S, Zhou Q, Chitale D, Li AR, Zakowski MF, Kris MG, Rusch VW, Azzoli CG, Seshan VE, Ladanyi M, Pao W. Prognostic and therapeutic implications of EGFR and KRAS mutations in resected lung adenocarcinoma. J Thorac Oncol. 2008 Feb;3(2):111-6. PubMed PMID: 18303429.

12. Heist RS, Christiani D. EGFR-targeted therapies in lung cancer: predictors of response and toxicity. Pharmacogenomics. 2009;10:59-68. Review.

13. Pao W, Miller VA. Epidermal growth factor receptor mutations, small-molecule kinase inhibitors, and non-small-cell lung cancer: current knowledge and future directions. J Clin Oncol 2005; 23: 2556-2568.

14. Cohen V, Agulnik JS, Ang C, Kasymjanova G, Batist G, Small D, et al. Epidermal growth factor receptor mutations detected by denaturing high-performanceliquid chromatography in nonsmall call lung cancer: impact on response to therapy with epidermal growth factor receptor-tyrosine kinase inhibitors. Cancer 2010;116:4215-32.

15. Sequist LV, Bell DW, Lynch TJ, Haber DA. Molecular predictors of response to epidermal growth factor receptor antagonists in non-small cell lung cancer. J Clin Oncol 2007; 25:587-595.

16. Jacman DM, Yeap BY, Sequist LV, Lindeman N, Holomes AJ, Joshi VA, et al. Exon 19 deletion mutation of epidermal growth factor receptor are associated with prolonged survival in non-small cell lung cancer patients treated with gefitinib or erlotinib. Clin Cancer Res 2006;12:3908-14.

17. Fukuoka $\mathrm{M}, \mathrm{Wu} \mathrm{YL}$, Thongprasert $\mathrm{S}$, Sunpaweravong $\mathrm{P}$, Leong SS, Sriuranpong $\mathrm{V}$, et al. Biomarker analyses and final overall survival results from a phase III, randomized, open-label, first-line study of gefitinib versus carboplatin/paclitaxel in clinically selected patients with advanced non-small-cell lung cancer in Asia (IPASS). J Clin Oncol 2011;29:2866-74.

18. R. Rosell, R. Gervais, A. Vergnenegre, B. Massuti, E. Felip, F. Cardenal, et al. Erlotinib versus chemotherapy (CT) in advanced non-small cell lung cancer (NSCLC) patients ( $p$ ) with epidermal growth factor receptor (EGFR) mutations: Interim results of the European Erlotinib Versus Chemotherapy (EURTAC) phase III randomized trial. ASCO 2011; Abstract 7503.

19. Zhou C, Wu YL, Chen G, Feng J, Liu XQ, Wang C, et al. Erlotinib versus chemotherapy as first-line treatment for patients with advanced EGFR mutationpositive non-small-cell lung cancer (OPTIMAL, CTONG-0802): a multicentre, open-label, randomised, phase 3 study. Lancet Oncol 2011;12:735-42. 